依 頼 論 文 日本補綴歯科学会第 122 回学術大会/臨床リレーセッション 2 「インプラントと天然歯の共存を考える補緅治療計画」

\title{
天然歯とインプラントの共存を研究から考元る
}

松下 恭之, 江崎 大輔, 古谷野 潔

\section{Biomechanical consideration for coexistence of implant and natural teeth}

\author{
Yasuyuki Matsushita, DDS, PhD, Daisuke Esaki, DDS, PhD and Kiyoshi Koyano, DDS, PhD
}

\begin{abstract}
抄 録
インプラント治療を始めた 30 年前にはインプラント部の咬合はやや低めで, また天然歯と連結することで インプラントを守るといった戦略が主流であった。近年ではインプラント自体のオッセオインテグレーショ ンは得られているが，上部構造に関する問題で転医してくる患者が増加しているように感じている，一方， インプラント上部構造に問題はみられないが，残存天然歯を喪失していき，一口腔単位としては，治療介入 が引き続き必要な状況にある症例も散見される．インプラントの信頼性が向上した現在，インプラントと天 然歯の双方を守っていく共存の時代へと変化してきたように感じる.
\end{abstract}

和文キーワード

補綴的偶発症, バスタブ曲線, スクリューの緩み, インプラント破折

\section{I. 緒言}

近年ではインプラントのオッセオインテグレーショ ンは得られているが，上部構造が受け入れられない, 壊れた，残存天然歯のトラブル等を訴える患者が増加 してきたように感じている。これからはインプラント と天然歯の双方を守りながら, 咀嚼機能を回復してい く必要があろう。インプラントと天然歯の共存を考え るにあたり, 1) 補綴装置の損傷, 2) 天然歯の保護といつ た $2 つ の$ 要素について, 研究の観点から考察する.

\section{II．補綴装置の損傷}

信頼性工学 (Reliability engineering) では, 工業製 品は使用期間によってその故障率に変化が見られると される。初期は製作工程中に含まれる欠陥等により故 障率が高く, 使用開始とともに劣化, 故障してしまう 時期である。不良品はこの時期に除外されてしまうた め, 故障は減少していき, 安定した時期を迎える。し かし, その時期を過ぎると, 部品の摩耗や劣化が蓄積
してきて故障が増加する。使用期間を横軸に，故障率 を縦軸にプロットした曲線の形状がバスタブのように みえることから, バスタブ曲線と呼ばれる ${ }^{1)}$ (図 1). Goodacre CJ ら $^{2)}$ はインプラントの偶発症に関するレ ビュー論文でインプラント補経の機械的偶発症を紹介 しているが, この曲線にそれらをあてはめるとすれば, 初期故障にあたるものには，スクリューの緩み，スク リューの破折, 前装材のチッピングなどがあげられる. 晚期のものでは, 上部構造の破折, インプラント破折, 摩耗などがあげられる。

\section{1.スクリューの緩み・破折}

Papaspyridakos $\mathrm{P}$ ら $^{3)}$ はインプラント治療の偶発症 に関するシステマティックレビューを行い, 最も多い 補経的偶発症はスクリューの破折で, 発生頻度は 5 年 で 10.4\%, 10 年で $20.8 \%$ と報告している. スクリュー が緩む原因には，1）締結力不足，2）初期緩み，3） 曲げモーメントの繰り返し負荷，4）スクリューの強 度不足, 5) 連結上部構造の適合不良などが挙げられる。 破折に関しては, 過剩締結力の負荷や過大応力の発生 など多くの状況要因が考えられ, 詳細な検討は別の機 


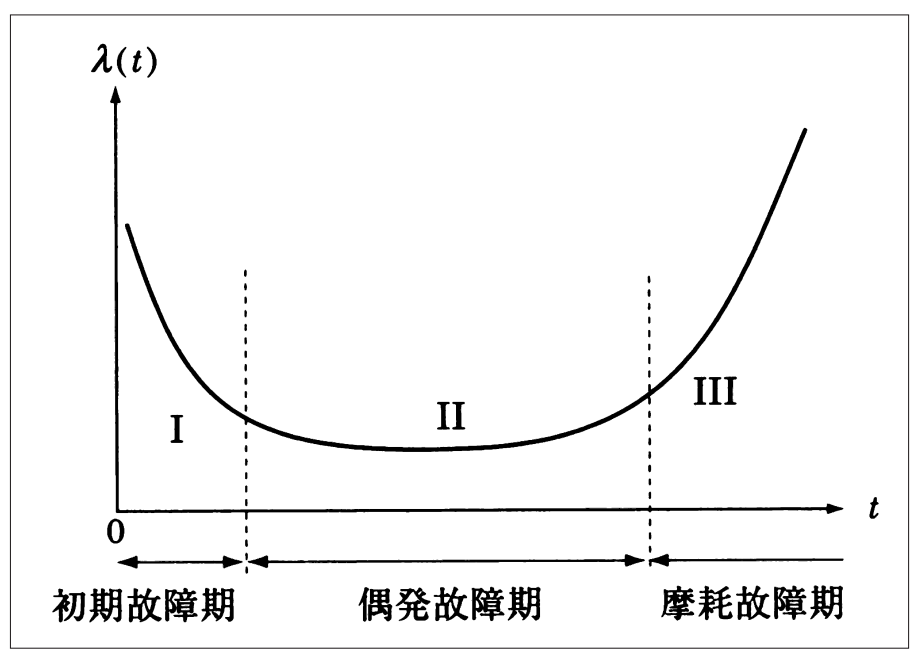

図 1 バスタブ曲線 文献 1 より改変引用

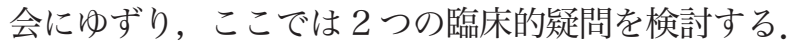

インプラントシステム, 上部構造の固定様式はスク リューの緩みに影響を与えるのか?

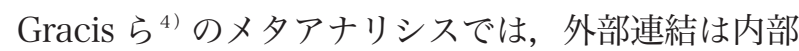
連結の 5 倍ほどスクリュー緩みが発生しやすかったと 報告している. Brånemark タイプに代表される外部連 結機構での外部ヘックス高さは $0.7 \mathrm{~mm}$ しかなく, 内 部連結型のものに比べ，その連結強度がかなり小さく, 曲げに弱いという構造に起因すると考えられる。

Vigolo ら ${ }^{5)}$ は外部連結型のインプラントを用いた前 向き臨床研究を行い, セメント固定とスクリュー固定 とで，4 年の中期的観察を行った結果，緩みを含む機 械的偶発症の発生については違いがみられなかつたと している. Nissan ら ${ }^{6)}$ は長期経過した症例 221 本のイ ンプラントへの後ろ向き研究を行い, セメント固定と スクリュー固定でアバットメントスクリューの緩みの 頻度, 歯肉の炎症, 辺縁骨吸収を統計的に観察した結果, いずれも有意にセメントのほうが有利であったと報告 している。一方 Sailer ら ${ }^{7)}$ のステマティックレビュー では，単独だとスクリュー固定に機械的偶発症が発生 しやすいが, 複数本数の連結では, セメント固定での 機械的偶発症の発生が増加する傾向が見られたとして いる.

スクリューの緩みには上部構造の製作方法，咬合調 整，インプラントの配置など数多くの因子が関わって いると考えられるため，単純に固定様式のみだけでな く，多因子的に捉える必要がある。
長期に使用したスクリューは交換すべきか?

緩んだアバットメントスクリューを SEM で観察し た Jabbari $ら^{8)}$ は装着から 31 カ月機能したスクリュー では，固着による粗面化がスクリューヘッド部で認 められたものの, スクリュー尖端には変化は見られ なかったとしている。では長期に機能した場合はど うであろうか? 機能期間 10 年のアバットメントス クリューを観察したところでは, 力学的なリスクの ない症例では表面の変化はほとんどみられなかった が，傾斜埋入されたインプラントに用いられていたス クリューの表面には，一部粗造な表面が認められた ${ }^{9}$. 生体力学的リスクがあるものでは定期的な交換も視野 にいれるべきかもしれない.いずれにしても, サンプ ル数の少ない観察結果しかないので, この分野での研 究が望まれる。

\section{2. 上部構造のチッピング・破損}

アクセスホールの存在によりスクリュー固定性 上部構造には脆弱性があることが予想されてきた。 Torrado ら ${ }^{10)}$ はスクリュー固定とセメント固定とで陶 材の破折強度を実験的に計測した結果, スクリュー固 定のほうが破折しやいと結論づけている。しかし同様 の実験を行った Zarone ら ${ }^{11)}$ は，両者に違いがみられ なかったとしている。一方 5 ユニットの連結冠に対し て動的負荷試験を行った Karl ら ${ }^{12)}$ は，スクリュー固定 ではセメント固定よりも有意に陶材の破折が生じたと しており，補緅デザインの影響を受ける可能性を示唆 している. 臨床的にインプラント支持陶材燒付鋳造冠 (PFM 冠) の長期予後を調査した Kinsel ら ${ }^{13)}$ は，対 合歯がインプラント支持 PFM 冠ではオッズ比が 7 倍, 
ブラキサーでナイトガードを使用しない症例ではオッ ズ比 2 倍であったと患者側の要素について言及してい る.

ジルコニアではどうだろうか？ Schwartz ら ${ }^{14)}$, Larsson ら ${ }^{15)}$ はチッピング発生率をそれぞれ $25 \%$, 34\%（3 年経過時）程度と報告している. Papaspyridakos ら ${ }^{3)}$ は前装材の破折発生を 5 年で $33.3 \%, 10$ 年では $66.6 \%$ と見込んでおり，ジルコニアではやや多 い. フレームが何であるにせよ長期経過してくると， 多くの補綴装置が何らかの問題を起こしていることに なる。インプラントは天然歯に比べ，上部構造の支持 面積が小さいため，バックアップするフレーム自体が 小さくなりやすい。 そのため隣接面や煩側面での破折 が多いものと考えられる. Marchack ${ }^{16)}$ はジルコニア フレームでの陶材破折例を検討し，フレームデザイン の修正を提唱しているが，これはメタルフレームにも 当てはまるものと考えられる。

\section{3. インプラントの破折}

インプラント体の破折の発生頻度は Goodacres ら 2 ) で $0.1 \%$, Jung ら ${ }^{17)}$ は $0.14 \%$ と少ないが, 患者にとっ ても主治医にとってもダメージが大きい偶発症と言え る. Albiol ら ${ }^{18)}$ は破折症例について，女性より男性に 多い，76\%は固定性補綴でカンチレバーを伴ってい る，80.9\%は臼歯部で発生したと報告している，Kim ら ${ }^{19)}$ は臼歯部，とりわけ第二大臼歯部に埋入されたシ ングルインプラントでカンチレバーの状態にあるもの では，スクリューの緩みやインプラント体の破折が多 く見られるため，カンチレバーが大きくならない正確 な位置に注意深く埋入することを提唱している，以上 より，インプラント破折ケースではやはり生体力学的 共通点が多い.

また近年の傾向として，内部連結型インプラントの 縦割れが散見されるが，Jimbo ら ${ }^{20)}$ はこの原因をミス フイットによるものと予想し，有限要素法による解析 を試みている. Jang ら ${ }^{21)}$ は内部連結型のインプラント の相互傾斜が大きくなると，インプラントレベルで印 象したスクリュー固定性連結冠のミスフィットが大き くなることを in vitroの実験から提示しており，イン プラントシステムごとの補綴的手法のコンセンサスを 確立すべきである。また Matono ら ${ }^{22)}$ はフッ素がチ夕 ン表面へ及ぼす影響を in vitro で調査し，破折のリス クとなることを提示しており，インプラント体破折と いう偶発症はブラキシズム，過大な咬合力などの生 体側の要因，応力を拡大させるカンチレバーなどの幾 何学的要因, インプラント体への化学的影響などのい
くつかの要素が重なりあい，その量が大きくなるほど, 破折発生までの期間が短縮されると考えられる。

\section{4. 上部構造の摩耗}

Janyavula ら ${ }^{23)}$ は上部構造材にジルコニア, 陶材, 金属を用いた場合の対合エナメル質の摩耗に関して in vitroでの摩耗試験を行っている. ジルコニアでは対顎 のエナメル質を著しく摩耗させるイメージがあるが, 実際のところ十分に研磨したジルコニアよりグレーズ したジルコニアのほうが対合の摩耗量は大きいが，グ レーズした陶材ほど大きくはなかったという結果を得 ており, 対合歯の摩耗については, 問題は大きく無い ことを示唆している。

\section{III. インプラントによる天然歯の保護}

\section{1. 固定性：天然歯との連結}

歯周病罹患によって動摇をきたした歯もインプラン トと連結することで, 動摇が止まり, 天然歯の予後を 上げることができる。しかしながら, Lang $~^{24)}$ によ れば，インプラントと天然歯の連結はインプラント自 体の長期成功率を 10\%下げるばかりでなく，天然歯自 体を沈下させるリスクの有ることを示しており，イン プラントによる，あるいは残存天然歯による独立した 咬合支持とすることが望ましいと考えられる。

\section{2. 可撤性義歯における天然支台歯の保護}

天然歯が残存する部分欠損は，部分床義歯として補 綴される。とりわけ遊離端義歯における支台歯は，補 綴設計によっては，支台歯に過大な負担を強いるた め, 支台歯の破折や周囲歯槽骨の吸収を引き起こし, 欠損を拡大しうる。 木原ら ${ }^{25)}$ は，インプラントとパー シャルデンチャーを組み合わせた Implant supported partial overdenture が従来の補経デザインを变えうる ことを模型実験により提示している。骨質が良好であ れば，ショートインプラントでも同様の効果が得られ ることは理論的には示されており ${ }^{26)}$ ，多くの症例に適 用されるようになれば，今後臨床での成績が期待され る.

\section{IV．結 論}

天然歯とインプラントが共存する口腔内で発生す る偶発症について, 基礎的研究と臨床疫学的文献レ ビューとから現状での臨床的留意事項を整理, 検討し た. 
信頼性工学の観点からは, 術者やシステムが強く関 与していると考えられる偶発症に関しては，それらの 要素を排除する, あるいは要素を検出し, その影響に 早期に対応することが口腔内におけるインプラントと 天然歯の共存への信頼を高めるものと考える.

\section{文献}

1）真壁 肇. 新版信頼性工学入門. 東京: 日本企画協会; 2012, 60-63.

2) Goodacre CJ, Kan JYK. Rungcharassaenget K. Clinical complications of osseointed implants. J Prosthet Dent 1999; 81: 537-552.

3) Papaspyridakos P, Chen CJ, Chuang SK, Weber HP, Gallucci GO. A systematic review of biologic and technical complications with fixed implant rehabilitations for edentulous patients. Int J Oral Maxillofac Implants 2012; 27: 102-110.

4) Gracis $S$, Michalakis K, Vigolo P, Vult von Steyern $P$, Zwahlen M, Sailer I. Internal vs. external connections for abutments/reconstructions: a systematic review. Clin Oral Implant Res 2012; 23(Suppl 6): 202-216.

5) Vigolo P, Givani A, Majzoub Z, Cordioli G. Cemented versus Screw-retained implant-supported single-tooth crowns: A 4year prospective clinical study. Int J Oral Maxillofac Implant 2004; 19: 260-265.

6) Sailer I, Mühlemann S, Zwahlen M, Hämmerle $\mathrm{CH}$, Schneider D. Cemented and screw-retained implant reconstructions: A systematic review of the survival and complication rates. Clin Oral Implant Research 2012; 23: 163-201.

7) Nissan J, Narobai D, Gross O, Ghelfan O, Chaushu G. Long-term outcome of cemented versus screwretained implant-supported partial restorations. Int $\mathrm{J}$ Oral Maxillofac Implants 2011; 26: 1102-1107.

8) Al Jabbari YS, Fournelle RA, Zinelis S, Iacopino AM. Biotribological behavior of two retrieved implant abutment screws after long-term use in vivo. Int $\mathrm{J}$ Oral Maxillofac Implants 2012; 27: 1474-1480.

9）松下恭之，的野良就，鳥谷浩平，國竹活代，江崎大 輔，古谷野 潔。長期使用したアバットメントスク リューの SEM 観察 平成 25 年度九州支部学術大会抄 録集 $2013: 26$.

10) Torrado E, Ercoli C, Al Mardini M, Graser GN, Tallents RH, Cordaro L. A comparison of the porcelain fracture resistance of screw-retained and cement-retained implant-supported metal-ceramic crowns. J Prosthet Dent 2004; 91: 532-537.

11) Zarone F, Sorrentino R, Traini T, Di lorio D, Caputi S. Fracture resitance of implant-supported screwversus cement-retained porcelain fused to metal single crowns:SEM fractographic analysis. Dental Materials 2007; 23: 296-301.

12) Karl M, Graef F, Taylor TD, Heckmann SM. In vitro effect of load cycling on metal-ceramic cementand screw-retained implant restorations. J Prosthet Dent 2007; 97: 137-140.

13) Kinsel RP, Lin D. Retrospective analysis of porcelain failures of mtal ceramic crowns and fixed partial dentures supported by 729 implants in 152 patients: Patient-specific and implant-specific predictors of ceramic failure. J Prosthet Dent 2009; 101: 388394.

14) Schwarz S, Schröder C, Hassel A, Bömicke W, Rammelsberg P. Survival and chipping of Zirconiabased and metal-ceramic implant-supported single crowns. Clin Implant Dentistry and Rel Res 2012; 14(suppl1): el 19-125.

15) Larsson C, Vult von Steyern P, Nilner K. A prospective study of implant-supported full-arch Yttriastabilized tetragonal zirconia polycrystal mandibular fixed dental prostheses: Three-year results, Int J Prosthodont 2010; 23: 364-369.

16) Marchack BW, Futatsuki Y, Marchack CB, White $\mathrm{SN}$. Customization of milled zirconia copings for allceramic crowns: a clinical report. J Prosthet Dent 2008; 99: 169-173.

17) Jung RE, Pjetursson BE, Glauser R, Zembic A, Zwahlen M, Lang NP. A systematic review of the 5 -year survival and complication rates of implantsupported single crowns. Clin Oral Impl Res 2008; 19: 119-130.

18) Gargallo Albiol J, Satorres-Nieto M, Puyuelo Capablo JL, Sánchez Garcés MA, Pi Urgell J, Gay Escoda C. Endosseous dental implant fractures an analysis of 21 cases. Med Oral Patol Oral Cir Bucal 2008; 13: e124-128.

19) Kim YK, Kim SG, Yun PY, Hwang JW, Son MK. Prognosis of single molar implants: a retrospective study. Int JPerio restorative Dent 2010; 30(4): 401-407.

20) Jimbo R, Halldin A, Janda M, Wennerberg A, Vandeweghe S. Vertical fracture and marginal bone loss of internal-connection implants: a finite element analysis. Int J Oral Maxillofac Implants 2013; 28: el71-176.

21) Jang HK, Kim S, Shim JS, Lee KW, Moon HS. Accuracy of Impressions for Internal-Connection Implant Prostheses with Various Divergent Angles. Int J Oral Maxillofac Implants 2011; 26: 1011-1015.

22) Matono Y. Nakagawa M, Ishukawa K, Terada Y. Effect of corrosion behavior of pure titanium and titanium alloy on fluoride addition in acidic environment by streptococcus mutans. Prosthodontic Research 
and Practice 2008; 7: 34-39.

23) Janyavula S, Lawson N, Cakir D, Beck P, Ramp LC, Burgess JO. The wear of polished and glazed zironia against enamel. J Prosthet Dent 2013; 109: 22-29.

24) Lang NP, Pjetursson BE, Tan K, Brägger U, Egger M, Zwahlen M. A systematic review of the survival and complication rates of fixed partial dentures (FPDs) after at least 5 years. II. Combined tooth-implantsupported FPDs. Clin Oral Implants Res 2004; 15: 643-653.

25）木原優文, 松下恭之, 徳久雅弘, 保志美砂子, 古谷野 潔. 遊離端義歯の後方支持として用いたインプラントの 効果. 日ロインプラント誌 $2003 ; 16 ： 214-225$.

26) Tada S, Stegaroiu R, Kitamura E, Miyakawa O,
Kusakari H. Influence of implant design and bone quality on stress/strain distribution in bone around implants: a 3-dimensional finite element analysis. Int J Oral Maxillofac Implants 2003; 18: 357-368.

\footnotetext{
著者連絡先 : 松下 恭之

T 812-8582 福岡市東区馬出 3-1-1

九州大学大学院歯学研究院口腔機能修復学 講座

Tel: 092-642-6361

Fax: 092-642-6380

E-mail: matsushi@dent.kyushu-u.ac.jp
} 